\title{
The Path to Perovskite on Silicon PV
}

\begin{abstract}
Henry J. Snaith ${ }^{1 *}$, Samuele Lilliu ${ }^{2}$
Henry J. Snaith is Professor of Physics in the Clarendon Laboratory at the University of Oxford and Fellow of the Royal Society. He has pioneered the field of perovskite solar cells and published more than 300 papers. He is the founder and Chief Scientist Officer of Oxford Photovoltaics, which holds the largest perovskite patent portfolio worldwide and focuses on developing and commercialising perovskite PV technology. In this interview, he discusses the present status and future prospects of perovskite PV. The interview is available at https://youtu.be/sbe9Z5oEs5o.
\end{abstract}

\section{Notable Achievements}

Samuele Lilliu (SL): How did you become one of the most influential scientists in perovskite solar cell research and what have been the most notable achievements to date?

Henry Snaith (HS): Perovskite solar cells are simply solar cells containing metal halide perovskites (Figure 1)., ${ }^{1,2}$

I first became aware of metal halide perovskites in 2009, when visiting some colleagues and collaborators in Japan. ${ }^{1}$ The first paper using metal halide perovskites in solar cells had just been published by the group of Prof. Tsutomu (Tom) Miyasaka (Toin University of Yokohama, Japan). ${ }^{3}$ Tom gave a presentation on this work and it was very impressive. The most remarkable aspect was that he just took two salts, led bromide $\left(\mathrm{PbBr}_{2}\right)$ and methylammonium bromide $\left(\mathrm{CH}_{3} \mathrm{NH}_{3} \mathrm{Br}\right)$, put them together in a solvent, and spin coated a film, which crystallized immediately during spin coating. ${ }^{3}$ At the same time, back in Oxford, I would been playing around with quantum dots led sulphide $(\mathrm{PbS})$ nanoparticles. ${ }^{4}$ They were extremely tedious to synthetize and it took a long time, weeks of work, to make devices. Whereas this perovskite material appeared to just form instantly. That was something that I found quite interesting.

I subsequently returned to the UK and managed to get a collaborative grant with one of my colleagues Takurou Murakami and I sent a PhD student back to Japan to learn how to make these perovskite materials. Back in Oxford we managed to integrate them into what we were working on at the time: dye sensitized solar cells (DSSCs). ${ }^{5-9}$ The device that Tom Miyasaka had developed ${ }^{3}$ was based on a porous $\mathrm{TiO}_{2}$ anode, where the anode is sensitized, typically with a dye. He used small perovskite nano-crystals and then infiltrated the device with an electrolyte. ${ }^{3}$ The big problem with this device was that the electrolyte dissolves the perovskite crystals, so the device lasted seconds. I think this is probably one of the reasons why that work was not instantly followed. It looked like it was quite interesting, but just led to unstable cells.

Whereas, in contrast, when we replaced the electrolyte with a solid-state organic hole-conductor into the perovskite device, we obtained films that would be stable for a thousand hours under sunlight, which was a massive step change.

The big shock, if you like, or the first shock, was just our first batch of devices were already $6 \%$ power conversion efficiency. At the time, DSSCs had hit a plateau of about $5 \%$ and for 3-5 years we could not get them any better. These perovskite devices were already more efficient on the first attempt and of course they rapidly stepped up. The first real surprise was that they worked instantly. Usually when trying a new material if you can get $1 \%$ efficiency you are pretty happy.

Following on from that, with the way we were processing and

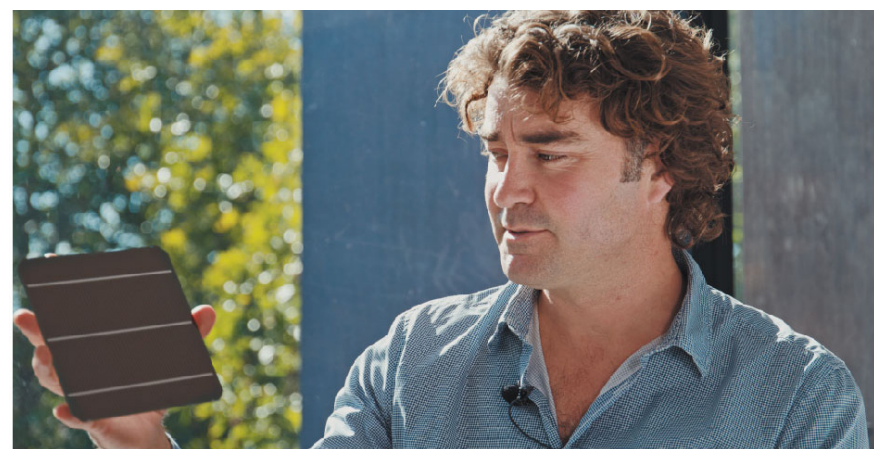

Figure 1 | Prof. Henry Snaith holding a 6 inch perovskite on Si wafer.

crystallizing the perovskite material, what we were getting was not just small nano-crystals but more of a polycrystalline material, with very long range crystalline order. We had a suspicion that we were also getting charge conduction in the perovskite material, so we made some test cells swapping out the porous $\mathrm{TiO}_{2}$, which is an electron conductor, with porous alumina $\left(\mathrm{Al}_{2} \mathrm{O}_{3}\right) \cdot{ }^{10}$ We tested these cells to see how they worked under the sunlight. We were not expecting highly functional solar cells because they had an insulator in place of one of the semiconductors, but surprisingly they actually worked better than the cells without $\mathrm{TiO}_{2}$ and we got a very big improvement in voltage. ${ }^{10}$ This was the first real breakthrough, where we realized the perovskite material did not just act as a light absorber but it also acted as a charge conductor in the cell. ${ }^{11}$

Following on from that work, in close succession, we started investigating whether we really needed this porous alumina scaffold. By making it thinner and thinner we improved current and device efficiency at extracting charge. ${ }^{12}$ When we looked at a cross section of these devices, they had a solid absorber layer of perovskite on top of a thin porous scaffold of alumina. ${ }^{12}$ This told us already that the solid perovskite material could conduct charge out of the device.

Now that might not seem very surprising, but at the time the paradigm was that as a solid absorber material you could either have a very expensive crystalline semiconductor with low defect density, or a cheap material that was easy to process from solution at low temperature, but with a lot of electronic disorder. ${ }^{13}$ The cheap materials would not work as well as the expensive materials, and to get them to work you had to blend multiple materials, typically one material that would conduct electrons and one that would conduct holes. ${ }^{14,15}$ In the case of the DSSC, the absorber was sandwiched between these two materials in a rather complex meso-structured or nano-structured device. ${ }^{16-20}$ The way of thinking was that

${ }^{1 *}$ Clarendon Laboratory, Department of Physics, University of Oxford, Oxford, UK. Contact Henry. J. Snaith. ${ }^{2}$ The UAE Centre for Crystallography, UAE 
materials either fell into a category of high disorder, but needed to be nano-structured, or low disorder and would work in a solid crystalline film. The perovskites had the best of both worlds. They worked as a solid crystalline film and they were very easy to process at low temperature; so they were clearly in a different category, a league of their own.

Moving on from that, we demonstrated quite clearly that they could work as a solid thin film and in fact now the embodiment of a perovskite solar cell is that on one side you have a charge selective material, maybe an n-type organic material, you have the perovskite absorber as a solid polycrystalline film (about 1 micron in thickness), then you have a p-type material (an organic charged conductor or a metal oxide), and an electrode on the top. So it is a very simple sandwich structure device that we call a planar heterojunction or double heterojunction. . $^{21,22}$

Since those first few publications in the end of 2012, starting from 2013, the research field of perovskite solar cells has absolutely exploded. To put it into context, in 2012 there were four publications on perovskite solar cells, in 2013 there were about sixty, last year in 2017 there were about 2,500, and this year there is probably going to be 5,000 by the end of the year. ${ }^{23}$ Publications in the field are growing exponentially now. We were very fortunate to be there right at the beginning and we have managed to stay in the front pack, ahead in certain aspects of the research. Obviously we have been lucky to be riding this wave and hopefully we will be still riding this wave through to fruition. So, the explosion of the field is the reason why we get so many citations for the work that we do.

\section{State-of-the Art Perovskite Materials}

SL: What are the state-of-the-art perovskite materials at the moment?

HS: Since 2012, when the field took off, the efficiency of the small lab-based cells was just over $10 \%$. In our first publication we reported $10.9 \%$ efficiency. ${ }^{10}$ Now that is increased to over $23 \%$ efficiency over the last 5-6 years. ${ }^{24}$ If we compare that to the efficiency of existing photovoltaics, mainstream multi-crystalline silicon photovoltaics is just under $23 \%$ efficiency. ${ }^{24,25}$ Perovskites have surpassed the efficiency of the most widespread deployable PV. That puts them in a very strong position to look like a real contender for utility-scale PV. However perovskites carry a lot more risk than silicon. Silicon has been in the field for a long time and it has proven the stability. Stability is a major component that we need to prove for perovskite solar cells.

Regarding the aspects that have led to improvements in perovskite PV efficiency, a lot has been done in terms of device structure engineering, by controlling the crystallization of the perovskite film and making thick high-quality perovskites.

That comes in part from choosing the right materials. We have made a transition from methylammonium lead triiodide $\left(\mathrm{CH}_{3} \mathrm{NH}_{3} \mathrm{PbI}_{3}\right)$, which is the workhorse of the first generation of perovskites, through to mixed cation and mixed anion materials. Perovskites are defined as any material that crystallises in the ABX structure, where $\mathrm{A}$ is an organic cation, $\mathrm{B}$ is a metal cations, and $\mathrm{X}$ is an halide anion. ${ }^{1}$ Typically a good quality perovskite might have formamidimium $\left(\mathrm{HC}\left(\mathrm{NH}_{2}\right)_{2}\right.$ or simply $\left.\mathrm{FA}\right)$ and cesium $(\mathrm{Cs})$ at the A cation site, led $(\mathrm{Pb})$ at the metal site, and a mixture of iodine (I) and bromine $(\mathrm{Br})$ at the halide site, in the $\mathrm{ABX}_{3}$ crystal structure. ${ }^{26,27}$

There are many people exploring multiple cations. There is for instance the addition of rubidium $\left(\mathrm{Rb}^{+}\right)^{28}$ and the addition of very small ions such as potassium $\left(\mathrm{K}^{+}\right)^{29}$ and sodium $\left(\mathrm{Na}^{+}\right)^{30-32}$. Actually, if you go smaller than Cs in the A site, the ion does not really fit into the perovskite structure. ${ }^{33}$ Much of the research reporting quadruple, quintuple, sextuple cations is probably not well understood. The perovskite is probably made of FA and Cs, sometimes with MA as well, and the other ions are really doing something else. They do have an impact there in the film, they may be going interstitially. They may be causing certain reactions on the surface of the crystal and the grain boundaries.

The other component in the efficiency improvement, has been controlling the crystallization, ${ }^{34-37}$ working out good ways to process these perovskite materials.

The perovskite absorber itself in principle has a pretty low defect density. ${ }^{38}$ There are not many defects and the defects that exist are not absolutely detrimental. ${ }^{39,40}$ They do not kill the performance, but limit the open circuit voltage ${ }^{41}$ One way to improve the voltage is to passivate the crystal. Here the term 'passivation' is used in a very broad term, because we do not really understand what is happening chemically. There are lots of routes of post-processing the films that improve, for instance, the radiative efficiency and the fraction of light re-emitted from the perovskite material. ${ }^{42-46}$ What we indicate with the term 'passivation' could be recrystallization of the surface, for example. ${ }^{47}$ Understanding the surface chemistry, the exact chemistry at the grain boundaries and in the buried interface is really important, because this has in part driven the performance improvements ${ }^{48}$ However, there is still a massive scope for further advances. We are currently at $23 \%$ efficiency for record cells in labs, but actually there is nothing stopping us towards $30 \%$ efficiency in a single junction cell. That will happen by achieving better control of the surface properties, in my view, of the perovskite absorber.

Coupled with that, there has been a lot of tuning and optimization of the contact materials. ${ }^{49,50}$ What is quite surprising is that we have not had to develop new contact materials. We just had to select materials that were already available either from the organic electronics field or from the DSSC or from thin film PV field. We have used metal oxides, organic semiconductors, and they seem to make very good electronic contact to the perovskite. ${ }^{51-53}$ However, tuning the properties of those materials, for instance doping of the contact materials, has all been part of getting the efficiency up and going up this ladder towards the Shockley-Queisser limit. ${ }^{54}$

\section{Multi-Junction Perovskite Solar Cells}

SL: What is the current progress of multi-junction perovskite devices?

HS: I mentioned the efficiency of a perovskite solar cell was $23 \%$ and that we could potentially get that up towards $30 \%$ efficiency. To someone not familiar with photovoltaics that seems like a pretty low number. Why are we chucking away two-thirds of our power? There are fundamental limits to the conversion of sunlight to electricity and they relate to the bandgap of the semiconductor that absorbs lights. With a very narrow band gap material you can absorb all the light over the solar spectrum and generate a very high current but you would not generate very high voltage. This is because the maximum voltage that can be generated is less than the bandgap, which is the difference in energy between the valence band and conduction band. With a very wide bandgap semiconductor you can generate a lot of voltage, but you are only absorbing a small fraction of the sunlight. Therefore, if a semiconductor has a bandgap of, for example, $3 \mathrm{eV}$ you would only absorb the UV part of the spectrum. However, you need to absorb from the UV to the visible and the infrared. This leads to a compromise, where a bandgap for a single absorber material is the optimum bandgap somewhere between $\sim 1$ to $\sim 1.5$ $\mathrm{eV}$, which can theoretically give a maximum efficiency of $\sim 30-32 \%{ }^{55}$

Actually there is a way to make cells more efficient. If you look at the global efficiency chart that is published by NREL, ${ }^{25}$ there are solar cells, which are $46 \%$ efficient, ${ }^{56}$ approaching $50 \%$, and they do that by not just having a single absorber, but having multiple absorbers on top of each other. In this way you absorb different parts of the solar spectrum in different cells. The top cells absorb the blue visible part of the spectrum and generate high voltage, while the cells behind will take out different sections of the solar spectrum generating a smaller and smaller voltage ${ }^{55}$ By doing this, we can extract more energy from the sunlight.

This is a strategy for perovskites that we are starting to pursue and it is looking very promising. ${ }^{55}$ Probably the simplest embodiment is 
to take a perovskite cell and stick it on top of silicon, which is the existing mainstream PV material. In this way we can improve the overall efficiency of that silicon cell. The present world record for perovskite on silicon is $27.3 \%$ efficiency. ${ }^{57}$ It is much higher than the $23 \%$ percent for a single junction perovskite cell and it is even higher than the all-time world record for crystalline silicon (using a very advanced technology), which is $26.7 \%{ }^{24}$ This is the point where perovskites start to take the lead. However, this does not just stop at a tandem cell. We can estimate what sort of efficiency we can get if we put three layers on top of each other. We could push the efficiency up to $40 \%$ efficiency, which is feasible. This could be achieved with two perovskite layers on silicon or even with all-perovskite multi-junction cell. ${ }^{58}$ This is where I believe the field has to go and is going, and it is somewhere where I think there will be a lot of excitement and interest over the next few years.

\section{Concentrator Photovoltaics}

SL: How can perovskite-Si multi-junction solar cells benefit from concentrator photovoltaics (CPV)?

HS: As scientists, we always try to think about what is the next step for improvement. For instance, going from single junctions to multi-junctions. Another way of improving efficiency is to concentrate sunlight or increase the intensity of the sunlight. Although you cannot get more sun hitting the earth, you can concentrate the sunlight. The result is that you generate a much higher voltage out of the solar cell. Light concentration is a well-established method in PV. Multi-junction cells that are $40 \%$ efficiency get boosted up to $50 \%$ efficiency by concentration. ${ }^{25}$ Therefore the next natural step for perovskites would be concentration.

A while ago, I personally had not given this much consideration as a realistic prospect. I would have to give some credit to my postdocs Zhiping Wang and Qianqian Lin, who one day showed me some of their results of intensity dependent measurements of perovskite solar cells. I thought this was very interesting. Scientifically it was quite intriguing. We ran some calculations and worked out that perovskites should operate very well up to many tens of thousands of solar irradiance in $\mathrm{mW} / \mathrm{cm}^{2}$ from concentrating standard sunlight $\left(100 \mathrm{~mW} / \mathrm{cm}^{2}\right.$ or equivalently 1 Sun $) .{ }^{59}$ Because we had been struggling to make big improvements with the stability under 1 Sun, how could we make these devices stable under 10 or 100 Suns illumination? ?9-61 $^{2}$

Over the last year or so I have convinced myself that this is a very good idea and I will try to convince you that maybe it is also quite a good idea. In our lab we have shown that this can be achieved with contemporary perovskite cells, where the $\sim 21 \%$ efficiency under 1 Sun can be raised up to $\sim 24 \%$ by concentrating the sunlight to 14.5 Suns. ${ }^{62}$ We have seen many hundreds of hour stability under 10 Suns illumination. ${ }^{62}$ So, they are progressing well and I would not say stability is an absolute critical factor now. In fact, if you think about a concentrating array, provided you can thermally sink the solar cell and have the heat radiated away, then in principle it can still operate at the same temperature as a flat-plate technology, depending on your concentrating optics.

The opportunity here, not with single junction perovskite but with very efficient multi-junction perovskite, is not to go for say 1000 fold concentration or 500 fold concentration that is required for present-day multi-junction cells. The reason why such a high concentration is required for conventional cells is because these cells are just so expensive to make. Commercial CPV are based on III-V semiconductors. ${ }^{63}$ Gallium arsenide $(\mathrm{GaAs} / \mathrm{Si})^{64}$ and multi-layer gallium indium phosphide cells with germanium (GaInP/GaInAs/ $\mathrm{Ge})^{24}$, for example, are made via epitaxial growth and cost tens of thousands of dollars per square metre. In contrast, perovskites are even cheaper than silicon to make and yet we think we will get close to similar efficiencies as III-Vs. Then we can think of deploying intermediate or so-called low-cost and low concentration factor, on the order of 10 to 30 fold concentration, with very efficient perovskite solar cells to deliver performance improvement. ${ }^{62}$

The other aspect that is riding in favour of CPV for perovskites, is that the trends in deployment are moving towards solar tracking. Already presently deployed mainstream modules are placed on a boom, in a single-axis tracking configuration, which could be combined with a low concentrator factor solar concentrator. ${ }^{65}$ There are also existing technologies that deploy these modules on two-axis trackers, in some high radiance areas. ${ }^{65}$

Overall, the more power we get out of a module the larger we offset the balance of systems (BOS) cost. ${ }^{62}$ As we move towards more powerful modules, we will move towards two-axis tracking, which will become the norm at some point. At that point, we will not have any additional cost in the tracking for CPV. What will affect the BOS cost will be the optics technology (e.g. parabolic mirrors). ${ }^{65}$ Ultimately, I think we will move to CPV. Although this gives another order of magnitude in the challenge of the stability issue, we believe this is surmountable by looking at new materials chemistry, new interface design, and other improvements. Therefore, CPV could be the path for the next generation beyond multi-junction perovskite cells.

\section{Lifetime Measurement Standards}

SL: What is the current status of standard lifetime measurements for perovskite solar cells?

HS: We can get extremely excited by efficiency and the remarkable performance of perovskites and the ease of which they can be processed, but of course we are all aware that no solar technology is of any worth unless it can last in the field. Silicon PV modules today will last for 25 years. That is proven and it is known they will last for 25 years because they have lasted for 25 years. At the moment we are in a situation where these perovskite materials work very well, but we need to ensure that they will last for 25 years. ${ }^{2,55}$ We do not have hindsight to know if the tests were doing to stress them are the right tests that will show up failures in the field. ${ }^{66}$ This is really at the core of what we should be doing in research. ${ }^{67}$

There is a slight discrepancy within the community between methodology for stressing perovskite solar cells, how to report stability, and what measurements indicate whether a solar cell is stable or not. ${ }^{6}$ I have had the pleasure of recently working with Peter Hacke from NREL and writing a paper on stability for perovskite solar cells. ${ }^{67}$ I learned a lot in the process about what has been done in the past with existing thin film and silicon cells. There is a lot we can learn from the existing industry.

Moreover with my role in Oxford Photovoltaics ${ }^{69} \mathrm{I}$ am exposed to that industrial side and industrial demand. There really complying to industry norms is an absolutely essential component. However, we also need to go further and discover new failure mechanisms. This is why doing lots of more advanced tests by comparing laboratory tests to real on-sun testing is going to be an essential component going forward over the next few years.

One thing that is presently lacking in the scientific community has been the ability to compare results of stability from one lab and stability from the other. There is a whole host of parameters, including the spectrum of light illuminating the cells, ${ }^{68}$ the temperature,,$^{27,70-73}$ whether the cell is under load or open circuit, ${ }^{74}$ the atmosphere, ${ }^{75-78}$ whether the cells are encapsulated and how they are encapsulated, ${ }^{79}$ and a wide range of other parameters. The real critical thing is that these results are reported, so it is very transparent as to exactly how a solar cell has been stressed. While you can make a comparison, what would be better is if standards emerged. ${ }^{67}$ In this way researchers have to comply with them and use them as the benchmark to establish if a cell is more stable than another and understand between laboratories where the chemistry is improving things or not.

From the European perspective there is quite a lot of motivation 
between different European funded projects to try to come up with some suggestions of standard lab practices, which will as closely as possible adhere to the International Electrotechnical Commission (IEC) standards.

On top of the stability stress, just measuring a perovskite solar cell is different to a normal cell. We have some issue of mobile ions in these materials. ${ }^{80-84}$ Again, there is effort to try to standardize the measurement technique. The key factor is that we have to either measure a stabilized steady state power output (measure at a fixed voltage over time and take the current until it stops changing) or max power point track (you track around the voltage until you stabilize the current), which are an essential component for quantifying efficiency. ${ }^{81,85,86}$

\section{Low Production Cost}

SL: What are the main factors affecting the manufacturing cost of perovskite modules? Can you talk about the current status of inkjet-printing for perovskite modules?

HS: Historically there has been a lot of activity on printed and flexible solar cells and lots of the work was done on organic solar cells. ${ }^{87,88}$ Commercially there has been a lot of work done on thin film copper indium gallium selenide solar cells $\left(\mathrm{Cu}(\mathrm{In}, \mathrm{Ga}) \mathrm{Se}_{2}\right.$ or CIGS). ${ }^{24,89,90}$ A company called Nanosolar raised many hundreds of millions to try to commercialize a printable CIGS technology. MiaSolé ${ }^{91}$ that ended up being taken over by Hanergy ${ }^{92}$ is selling a flexible CIGS technology. There is this dream that printable flexible PV should enable more than rigid based PV. One of the motivating factors is cost. The presumption that reel-to-reel printing will be much less expensive than standard semiconductor processing. However, we really have to look at what is the cost of existing processing of silicon PV cells and, in fact, the cost of equipment and manufacturing has dropped by orders of magnitude over the last decade..$^{93}$ Therefore now the capital infrastructure for a silicon line, say $1 \mathrm{GW}$ line, is only a small fraction of the overall cost in cents per Watt. About 2-4 cents per Watt comes from the capital infrastructure, when you depreciate it over seven years. From this perspective, it is not obvious that you are going to get a cost advantage from reel-to-reel printing.

There are many more challenges as well. One of them is that every process has to be coinciding in the production line at the same rate or you need longer routes to go through. ${ }^{94-96}$ There are more challenges for the printing rather than batch processing. That means it will take a longer time until this technology gets to the market, but it does not mean that ultimately there is not an opportunity. In fact, I strongly believe there is an opportunity for reel-to-reel printing, but there are lots of aspects we need to solve.

One of the main opportunities is to have a laminatable foil PV, which for example can be placed in a building or on the bodywork of electric cars. ${ }^{97} \mathrm{~A}$ PV foil laminated over the outer shell of an electric car that produces very high power could be a fantastic way of offsetting the requirement to charge every so often its batteries. So there are numerous applications for flexible and lightweight solar cells. ${ }^{98,99}$

The key aspect we have to tackle is the solvent system we use to dissolve and deposit the perovskite material. Most of the academic works are still done with a mixture of dimethylformamide (DMF) and dimethyl sulfoxide (DMSO). ${ }^{100-103}$ However, DMF is not compatible with high-volume manufacturing. ${ }^{104,105}$ We also need to control the viscosity and do more work on advancing printing techniques such as inkjet-printing, ${ }^{106}$ slot-dye coating, ${ }^{107}$ or spray-coating. ${ }^{108}$ These large area coating techniques need to be developed. At the moment, most academic work is done on spin coating, which is not a methodology compatible with manufacturing.

One of the bits of work we did a few years ago in this line is moving away from DMF to acetonitrile (ACN). ${ }^{104} \mathrm{ACN}$ is not a perfect solvent (for perovskites) and you certainly would not want to drink it, but it is allowed in manufacturing and it is much better than
DMF. We found that if we bubbled methylamine through ACN we could then use it to solvate the organic salts. ${ }^{104}$ We are now progressing with this work and looking at other solvent systems that could be more compatible with printing. I think this is an approach that could lead to printable PV cells with very high quality of material.

Another advantage, if we think about deposition methodologies, is that you can reel-to-reel via vapour. In fact one of the leading organic PV companies (Heliatek ${ }^{109}$ ) is manufacturing vapour deposited organic PV on reel-to-reel. Therefore there is an opportunity for reel-to-reel perovskite solar cells apart from batch processing. We need to understand whether we want to do vapour or solution processing, but there is still uncertainty. In the academic literature, 95\% of the works, maybe $99 \%$ of the papers (I haven't counted up), are on solution processed perovskites, and only $1 \%$ is on vapour deposited. That is not because solution processed PV is much better (or certainly not fundamentally better) than vapour deposited PV. It is simply because there is more capital investment to get an evaporator and get it working than to buy a spin coater. In my research group ( 25 people), we have 3 spin coaters and they cost $£ 5000$ each. In comparison, an evaporator may cost $£ 200,000$ and will only service 2-3 scientists. Therefore the rate and cost of getting into the field for evaporation is high, but we will see more and more activity in this area. ${ }^{110,111}$ As more and more groups are getting this capability, will see growth in this area of research over the next few years.

Moving towards multi-junction cells I expect vapour deposited cells to advance more quickly than the solution processed cells.

\section{Commercialisation}

SL: What is the current status of commercial perovskite modules?

HS: As the research field advances there is more and more of the developments being patent protected and this is also leading to the emergence of a number of companies trying to commercialize perovskite $\mathrm{PV}^{2,112}$ For instance, there is a company called Hangzhou Microquanta Semiconductor ${ }^{113}$ in China that is trying to produce thin film perovskite modules, as far as I am aware, on glass. As a thin film stand-alone perovskite product, there is a company in Poland called Saule Technologies ${ }^{114}$ that is trying to do inkjet-printed perovskites on flexible substrates. There is a few companies in the US. One is called Hunt Energy Enterprises. ${ }^{115}$ We do not really know what they are doing, they are quite opaque. There is another newly formed company called Swift Solar ${ }^{116}$ and they are working on flexible multi-junction perovskite solar cells.

The company closest to my heart is Oxford Photovoltaics. ${ }^{69} \mathrm{I}$ am co-founder and Chief Scientific Officer of Oxford PV. We are focusing on the perovskite on silicon technology and we certainly think of ourselves as the first mover in this technology. We think perovskite on silicon is the most practical deployment strategy. The wafer in Figure 2 looks to all intents and purposes like a silicon wafer but it is actually a perovskite on silicon wafer made in the Oxford PV facility in Brandenburg (Germany), where we are scaling up to full size.

Fortunately when talking about silicon cells, the wafer in Figure 2 is full size, so the scaling challenge is not that hard. It has taken a lot of effort but we can now make very efficient cells of this 6 inch wafer format, which is full scale. ${ }^{57}$ What we are doing now is trying to ramp up the volume towards pilot level manufacturing and then going beyond. One of the key targets in entering the silicon PV industry is to match the stability of silicon. There is no hiding away and offering a short lifetime product. ${ }^{2}$ For that in Oxford PV we have been laminating these cells and putting them into mini modules and stressing them through all the International Electrotechnical Commission (IEC) environmental stress tests. These devices are showing very good progress, not just to pass IEC but to go well beyond, which is a requirement.

The strategy of Oxford PV is also to license and work with joint development partners who are existing in the silicon manufacturing chain because in that way the existing value chain can be capitalized 


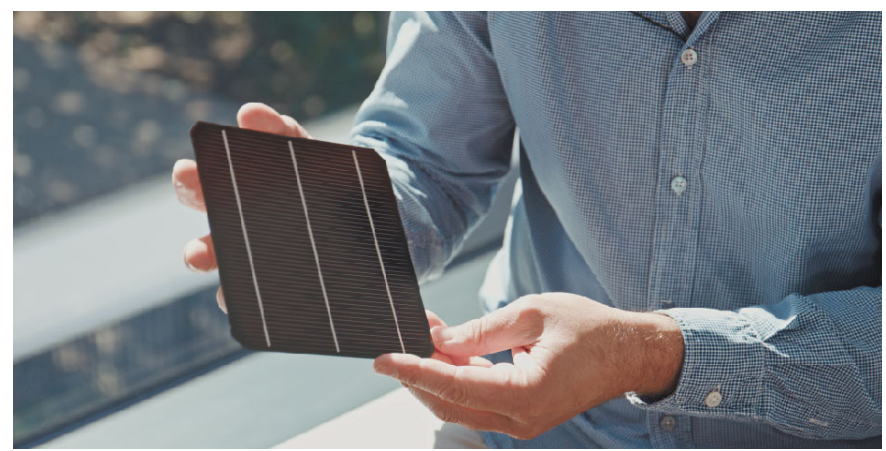

Figure 2 | 6 inch perovskite on Si wafer fabricated at Oxford PV.

upon and instead of competing against the silicon industry will actually enhance it. ${ }^{55}$ That is something perovskites could do. They could literally be the next generation of silicon cells in the first instance.

Ultimately we see many deployment strategies, we see the flexible, we see the thin film, and especially the all perovskite multi-junction coming through. My prediction would certainly be that the perovskite on silicon will be the first product in the market, and then beyond that we will see other technologies coming in.

\section{References}

1 Green, M. A., Ho-Baillie, A. \& Snaith, H. J. The emergence of perovskite solar cells. Nature Photonics 8, 506, (2014).

2 Snaith, H. J. Present status and future prospects of perovskite photovoltaics. Nature Materials 17, 372-376, (2018).

3 Kojima, A., Teshima, K., Shirai, Y. \& Miyasaka, T. Organometal Halide Perovskites as Visible-Light Sensitizers for Photovoltaic Cells. Journal of the American Chemical Society 131, 6050-6051, (2009).

4 Neo, D. C. J., Cheng, C., Stranks, S. D., Fairclough, S. M., Kim, J. S., Kirkland, A. I., Smith, J. M., Snaith, H. J., Assender, H. E. \& Watt, A. A. R. Influence of Shell Thickness and Surface Passivation on PbS/CdS Core/Shell Colloidal Quantum Dot Solar Cells. Chemistry of Materials 26, 4004-4013, (2014).

5 Snaith, H. J. Estimating the Maximum Attainable Efficiency in Dye-Sensitized Solar Cells. Advanced Functional Materials 20, 13-19, (2010).

6 Snaith, H. J. \& Ducati, C. SnO2-Based Dye-Sensitized Hybrid Solar Cells Exhibiting Near Unity Absorbed Photon-to-Electron Conversion Efficiency. Nano Letters 10, 1259-1265, (2010).

7 Brown, M. D., Suteewong, T., Kumar, R. S. S., D’Innocenzo, V., Petrozza, A., Lee, M. M., Wiesner, U. \& Snaith, H. J. Plasmonic Dye-Sensitized Solar Cells Using Core-Shell Metal-Insulator Nanoparticles. Nano Letters 11, 438-445, (2011).

8 Hardin, B. E., Snaith, H. J. \& McGehee, M. D. The renaissance of dye-sensitized solar cells. Nature Photonics 6, 162, (2012).

9 O'Regan, B. \& Grätzel, M. A low-cost, high-efficiency solar cell based on dye-sensitized colloidal TiO2 films. Nature 353, 737, (1991).

10 Lee, M. M., Teuscher, J., Miyasaka, T., Murakami, T. N. \& Snaith, H. J. Efficient hybrid solar cells based on meso-superstructured organometal halide perovskites. Science 338, (2012).

11 Stranks, S. D., Eperon, G. E., Grancini, G., Menelaou, C., Alcocer, M. J. P., Leijtens, T., Herz, L. M., Petrozza, A. \& Snaith, H. J. Electron-Hole Diffusion Lengths Exceeding 1 Micrometer in an Organometal Trihalide Perovskite Absorber. Science 342, 341-344, (2013).

12 Ball, J. M., Lee, M. M., Hey, A. \& Snaith, H. J. Low-temperature processed meso-superstructured to thin-film perovskite solar cells. Energy \& Environmental Science 6, 1739-1743, (2013).

13 Günes, S., Neugebauer, H. \& Sariciftci, N. S. Conjugated Polymer-Based Organic Solar Cells. Chemical Reviews 107, 1324-1338, (2007).

14 Park, S. H., Roy, A., Beaupré, S., Cho, S., Coates, N., Moon, J. S., Moses, D., Leclerc, M., Lee, K. \& Heeger, A. J. Bulk heterojunction solar cells with internal quantum efficiency approaching 100\%. Nature Photonics 3, 297, (2009).

15 Sariciftci, N. S., Smilowitz, L., Heeger, A. J. \& Wudl, F. Photoinduced Electron Transfer from a Conducting Polymer to Buckminsterfullerene. Science 258,
1474-1476, (1992).

16 Hagfeldt, A., Boschloo, G., Sun, L., Kloo, L. \& Pettersson, H. Dye-Sensitized Solar Cells. Chemical Reviews 110, 6595-6663, (2010).

17 Snaith, H. J., Schmidt-Mende, L., Grätzel, M. \& Chiesa, M. Light intensity, temperature, and thickness dependence of the open-circuit voltage in solid-state dye-sensitized solar cells. Physical Review B 74, 045306, (2006).

18 Snaith, H. J. \& Grätzel, M. Enhanced charge mobility in a molecular hole transporter via addition of redox inactive ionic dopant: Implication to dye-sensitized solar cells. Applied Physics Letters 89, 262114, (2006).

19 Snaith, H. J. \& Schmidt-Mende, L. Advances in Liquid-Electrolyte and Solid-State Dye-Sensitized Solar Cells. Advanced Materials 19, 3187-3200, (2007).

20 Snaith, H. J., Moule, A. J., Klein, C., Meerholz, K., Friend, R. H. \& Grätzel, M. Efficiency Enhancements in Solid-State Hybrid Solar Cells via Reduced Charge Recombination and Increased Light Capture. Nano Letters 7, 33723376, (2007).

21 Liu, M., Johnston, M. B. \& Snaith, H. J. Efficient planar heterojunction perovskite solar cells by vapour deposition. Nature 501, (2013).

22 Kim, H.-S., Lee, C.-R., Im, J.-H., Lee, K.-B., Moehl, T., Marchioro, A., Moon, S.-J., Humphry-Baker, R., Yum, J.-H., Moser, J. E., Grätzel, M. \& Park, N.G. Lead Iodide Perovskite Sensitized All-Solid-State Submicron Thin Film Mesoscopic Solar Cell with Efficiency Exceeding 9\%. Scientific Reports 2, 591, (2012).

23 Scopus, https://www.scopus.com (2018).

24 Green, M. A., Hishikawa, Y., Dunlop, E. D., Levi, D. H., Hohl-Ebinger, J. \& Ho-Baillie, A. Solar cell efficiency tables (version 52). Progress in Photovoltaics: Research and Applications 26, 427-436, (2018).

25 NREL, https://www.nrel.gov/pv/ (2018).

26 Eperon, G. E., Stranks, S. D., Menelaou, C., Johnston, M. B., Herz, L. M. \& Snaith, H. J. Formamidinium lead trihalide: a broadly tunable perovskite for efficient planar heterojunction solar cells. Energy \& Environmental Science 7, 982-988, (2014).

27 Lee, J.-W., Kim, D.-H., Kim, H.-S., Seo, S.-W., Cho, S. M. \& Park, N.-G. Formamidinium and Cesium Hybridization for Photo- and Moisture-Stable Perovskite Solar Cell. Advanced Energy Materials 5, 1501310, (2015).

28 Saliba, M., Matsui, T., Domanski, K., Seo, J.-Y., Ummadisingu, A., Zakeeruddin, S. M., Correa-Baena, J.-P., Tress, W. R., Abate, A., Hagfeldt, A. \& Grätzel, M. Incorporation of rubidium cations into perovskite solar cells improves photovoltaic performance. Science 354, 206, (2016).

29 Abdi-Jalebi, M., Andaji-Garmaroudi, Z., Cacovich, S., Stavrakas, C., Philippe, B., Richter, J. M., Alsari, M., Booker, E. P., Hutter, E. M., Pearson, A. J., Lilliu, S., Savenije, T. J., Rensmo, H., Divitini, G., Ducati, C., Friend, R. H. \& Stranks, S. D. Maximizing and stabilizing luminescence from halide perovskites with potassium passivation. Nature 555, 497, (2018).

30 Abdi-Jalebi, M., Pazoki, M., Philippe, B., Dar, I. M., Alsari, M., Sadhanala, A., Divitini, G., Imani, R., Lilliu, S., Kullgren, J., Rensmo, H., Grätzel, M. \& Friend, R. H. Dedoping of Lead Halide Perovskites Incorporating Monovalent Cations. ACS nano 12, 7301-7311, (2018).

31 Bag, S. \& Durstock, M. F. Large Perovskite Grain Growth in Low-Temperature Solution-Processed Planar p-i-n Solar Cells by Sodium Addition. ACS Applied Materials \& Interfaces 8, 5053-5057, (2016).

32 Abdi-Jalebi, M., Dar, M. I., Sadhanala, A., Senanayak, S. P., Franckevičius, M., Arora, N., Hu, Y., Nazeeruddin, M. K., Zakeeruddin, S. M., Grätzel, M. \& Friend, R. H. Impact of Monovalent Cation Halide Additives on the Structural and Optoelectronic Properties of $\mathrm{CH}_{3} \mathrm{NH}_{3} \mathrm{PbI}_{3}$ Perovskite. Advanced Energy Materials 6, 1502472, (2016).

33 Filip, M. R., Eperon, G. E., Snaith, H. J. \& Giustino, F. Steric engineering of metal-halide perovskites with tunable optical band gaps. Nature Communications 5, 5757, (2014).

34 Moore, D. T., Sai, H., Tan, K. W., Smilgies, D.-M., Zhang, W., Snaith, H. J., Wiesner, U. \& Estroff, L. A. Crystallization Kinetics of Organic-Inorganic Trihalide Perovskites and the Role of the Lead Anion in Crystal Growth. Journal of the American Chemical Society 137, 2350-2358, (2015).

35 Wang, F., Yu, H., Xu, H. \& Zhao, N. HPbI3: A New Precursor Compound for Highly Efficient Solution-Processed Perovskite Solar Cells. Advanced Functional Materials 25, 1120-1126, (2015). 
36 Alsari, M., Bikondoa, O., Bishop, J., Abdi-Jalebi, M., Y. Ozer, L., Hampton, M., Thompson, P., T. Hörantner, M., Mahesh, S., Greenland, C., Macdonald, J. E., Palmisano, G., Snaith, H. J., Lidzey, D. G., Stranks, S. D., Friend, R. H. \& Lilliu, $\mathrm{S}$. In situ simultaneous photovoltaic and structural evolution of perovskite solar cells during film formation. Energy \& Environmental Science 11, 383-393, (2018).

Lilliu, S., Griffin, J., Barrows, A. T., Alsari, M., Curzadd, B., Dane, T. G., Bikondoa, O., Macdonald, J. E. \& Lidzey, D. G. Grain rotation and lattice deformation during perovskite spray coating and annealing probed in situ by GIWAXS. CrystEngComm 18, 5448-5455, (2016).

38 Kim, J., Lee, S.-H., Lee, J. H. \& Hong, K.-H. The Role of Intrinsic Defects in Methylammonium Lead Iodide Perovskite. The Journal of Physical Chemistry Letters 5, 1312-1317, (2014).

39 Steirer, K. X., Schulz, P., Teeter, G., Stevanovic, V., Yang, M., Zhu, K. \& Berry, J. J. Defect Tolerance in Methylammonium Lead Triiodide Perovskite. ACS Energy Letters 1, 360-366, (2016)

40 Yin, W.-J., Shi, T. \& Yan, Y. Unusual defect physics in $\mathrm{CH}_{3} \mathrm{NH}_{3} \mathrm{PbI}_{3}$ perovskite solar cell absorber. Applied Physics Letters 104, 063903, (2014).

41 Luo, D., Yang, W., Wang, Z., Sadhanala, A., Hu, Q., Su, R., Shivanna, R., Trindade, G. F., Watts, J. F., Xu, Z., Liu, T., Chen, K., Ye, F., Wu, P., Zhao, L., Wu, J., Tu, Y., Zhang, Y., Yang, X., Zhang, W., Friend, R. H., Gong, Q., Snaith, H. J. \& Zhu, R. Enhanced photovoltage for inverted planar heterojunction perovskite solar cells. Science 360, 1442-1446, (2018).

42 Noel, N. K., Abate, A., Stranks, S. D., Parrott, E. S., Burlakov, V. M., Goriely, A. \& Snaith, H. J. Enhanced Photoluminescence and Solar Cell Performance via Lewis Base Passivation of Organic-Inorganic Lead Halide Perovskites. ACS Nano 8, 9815-9821, (2014).

43 De Marco, N., Zhou, H., Chen, Q., Sun, P., Liu, Z., Meng, L., Yao, E.-P., Liu, Y. Schiffer, A. \& Yang, Y. Guanidinium: A Route to Enhanced Carrier Lifetime and Open-Circuit Voltage in Hybrid Perovskite Solar Cells. Nano Letters 16, 1009-1016, (2016).

44 Abate, A., Saliba, M., Hollman, D. J., Stranks, S. D., Wojciechowski, K., Avolio, R., Grancini, G., Petrozza, A. \& Snaith, H. J. Supramolecular Halogen Bond Passivation of Organic-Inorganic Halide Perovskite Solar Cells. Nano Letters 14, 3247-3254, (2014).

deQuilettes, D. W., Koch, S., Burke, S., Paranji, R. K., Shropshire, A. J., Ziffer M. E. \& Ginger, D. S. Photoluminescence Lifetimes Exceeding $8 \mu$ s and Quantum Yields Exceeding 30\% in Hybrid Perovskite Thin Films by Ligand Passivation. ACS Energy Letters 1, 438-444, (2016).

Pazos-Outón, L. M., Szumilo, M., Lamboll, R., Richter, J. M., Crespo-Quesada, M., Abdi-Jalebi, M., Beeson, H. J., Vrućinić, M., Alsari, M., Snaith, H. J., Ehrler, B., Friend, R. H. \& Deschler, F. Photon recycling in lead iodide perovskite solar cells. Science 351, 1430-1433, (2016).

Son, D.-Y., Lee, J.-W., Choi, Y. J., Jang, I.-H., Lee, S., Yoo, P. J., Shin, H., Ahn, N., Choi, M., Kim, D. \& Park, N.-G. Self-formed grain boundary healing layer for highly efficient $\mathrm{CH}_{3} \mathrm{NH}_{3} \mathrm{PbI}_{3}$ perovskite solar cells. Nature Energy 1, 16081, (2016)

48 Abdi-Jalebi, M., Andaji-Garmaroudi, Z., Pearson, A. J., Divitini, G., Cacovich, S., Philippe, B., Rensmo, H., Ducati, C., Friend, R. H. \& Stranks, S. D. Potassium- and Rubidium-Passivated Alloyed Perovskite Films: Optoelectronic Properties and Moisture Stability. ACS Energy Letters, 2671-2678, (2018).

C. M., Zu, F., Paulke, A., Toro, L. P., Koch, N. \& Neher, D. Reduced Interface-Mediated Recombination for High Open-Circuit Voltages in $\mathrm{CH}_{3} \mathrm{NH}_{3} \mathrm{PbI}_{3}$ Solar Cells. Advanced Materials 29, 1700159, (2017).

50 Abdi-Jalebi, M., Dar, M. I., Sadhanala, A., Senanayak, S. P., Giordano, F., Zakeeruddin, S. M., Grätzel, M. \& Friend, R. H. Impact of a Mesoporous Titania-Perovskite Interface on the Performance of Hybrid Organic-Inorganic Perovskite Solar Cells. The Journal of Physical Chemistry Letters 7, 3264-3269, (2016).

51 Hartmann, C., Sadoughi, G., Félix, R., Handick, E., Klemm, H. W., Peschel, G., Madej, E., Fuhrich, A. B., Liao, X., Raoux, S., Abou-Ras, D., Wargulski, D., Schmidt, T., Wilks, R. G., Snaith, H. \& Bär, M. Spatially Resolved Insight into the Chemical and Electronic Structure of Solution-Processed Perovskites-Why to (Not) Worry about Pinholes. Advanced Materials Interfaces 5, 1701420, (2018).
L. M., Johnston, M. B., Riede, M. K., Snaith, H. J., Koch, N., Barlow, S. \& Marder, S. R. Modification of the fluorinated tin oxide/electron-transporting material interface by a strong reductant and its effect on perovskite solar cell efficiency. Molecular Systems Design \& Engineering, (2018).

53 Hou, Y., Du, X., Scheiner, S., McMeekin, D. P., Wang, Z., Li, N., Killian, M. S., Chen, H., Richter, M., Levchuk, I., Schrenker, N., Spiecker, E., Stubhan, T., Luechinger, N. A., Hirsch, A., Schmuki, P., Steinrück, H.-P., Fink, R. H., Halik, M., Snaith, H. J. \& Brabec, C. J. A generic interface to reduce the efficiency-stability-cost gap of perovskite solar cells. Science 358, 1192, (2017).

54 Shockley, W. \& Queisser, H. J. Detailed Balance Limit of Efficiency of p-n Junction Solar Cells. Journal of Applied Physics 32, 510-519, (1961).

55 Eperon, G. E., Hörantner, M. T. \& Snaith, H. J. Metal halide perovskite tandem and multiple-junction photovoltaics. Nature Reviews Chemistry 1, 0095, (2017).

56 Dimroth, F., Tibbits, T. N. D., Niemeyer, M., Predan, F., Beutel, P., Karcher, C., Oliva, E., Siefer, G., Lackner, D., Fuß-Kailuweit, P., Bett, A. W., Krause, R., Drazek, C., Guiot, E., Wasselin, J., Tauzin, A. \& Signamarcheix, T. Four-Junction Wafer-Bonded Concentrator Solar Cells. IEEE Journal of Photovoltaics 6, 343-349, (2016).

57 Oxford $P V$ sets world record for perovskite solar cell, https://www.oxfordpv. com/news/oxford-pv-sets-world-record-perovskite-solar-cell (2018).

58 Hörantner, M. T., Leijtens, T., Ziffer, M. E., Eperon, G. E., Christoforo, M. G., McGehee, M. D. \& Snaith, H. J. The Potential of Multijunction Perovskite Solar Cells. ACS Energy Letters 2, 2506-2513, (2017).

59 Lin, Q., Wang, Z., Snaith, H. J., Johnston, M. B. \& Herz, L. M. Hybrid Perovskites: Prospects for Concentrator Solar Cells. Advanced Science 5, 1700792, (2018).

60 Leijtens, T., Eperon, G. E., Pathak, S., Abate, A., Lee, M. M. \& Snaith, H. J. Overcoming ultraviolet light instability of sensitized $\mathrm{TiO} 2$ with meso-superstructured organometal tri-halide perovskite solar cells. Nature Communications $\mathbf{4}$, 2885, (2013).

61 Conings, B., Drijkoningen, J., Gauquelin, N., Babayigit, A., D’Haen, J., D’Olieslaeger, L., Ethirajan, A., Verbeeck, J., Manca, J., Mosconi, E., Angelis, F. D. \& Boyen, H.-G. Intrinsic Thermal Instability of Methylammonium Lead Trihalide Perovskite. Advanced Energy Materials 5, 1500477, (2015).

62 Wang, Z., Lin, Q., Wenger, B., Christoforo, G. M., Lin, Y.-H., Klug, M. T., Johnston, M. B., Herz, L. M. \& Snaith, H. J. High irradiance performance of metal halide perovskites for concentrator photovoltaics. Nature Energy, 1-7, (2018).

63 Cotal, H., Fetzer, C., Boisvert, J., Kinsey, G., King, R., Hebert, P., Yoon, H. \& Karam, N. III-V multijunction solar cells for concentrating photovoltaics. Energy \& Environmental Science 2, 174-192, (2008).

64 Essig, S., Allebé, C., Remo, T., Geisz, J. F., Steiner, M. A., Horowitz, K., Barraud, L., Ward, J. S., Schnabel, M., Descoeudres, A., Young, David L., Woodhouse, M., Despeisse, M., Ballif, C. \& Tamboli, A. Raising the one-sun conversion efficiency of III-V/Si solar cells to $32.8 \%$ for two junctions and $35.9 \%$ for three junctions. Nature Energy 2, 17144, (2017).

65 Apostoleris, H., Stefancich, M. \& Chiesa, M. Tracking-integrated systems for concentrating photovoltaics. Nature Energy 1, 16018, (2016).

66 Asghar, M. I., Zhang, J., Wang, H. \& Lund, P. D. Device stability of perovskite solar cells - A review. Renewable and Sustainable Energy Reviews 77, 131-146, (2017).

67 Snaith, H. J. \& Hacke, P. Enabling reliability assessments of pre-commercial perovskite photovoltaics with lessons learned from industrial standards. $\mathrm{Na}$ ture Energy 3, 459-465, (2018).

68 Domanski, K., Alharbi, E. A., Hagfeldt, A., Grätzel, M. \& Tress, W. Systematic investigation of the impact of operation conditions on the degradation behaviour of perovskite solar cells. Nature Energy 3, 61-67, (2018).

69 Oxford Photovoltaics, https://www.oxfordpv.com/ (2018).

70 Leijtens, T., Eperon, G. E., Noel, N. K., Habisreutinger, S. N., Petrozza, A. \& Snaith, H. J. Stability of Metal Halide Perovskite Solar Cells. Advanced Energy Materials 5, 1500963, (2015).

71 Bush, K. A., Bailie, C. D., Chen, Y., Bowring, A. R., Wang, W., Ma, W., Leijtens, T., Moghadam, F. \& McGehee, M. D. Thermal and Environmental Stability of Semi-Transparent Perovskite Solar Cells for Tandems Enabled by a Solution-Processed Nanoparticle Buffer Layer and Sputtered ITO Electrode. 
Advanced Materials 28, 3937-3943, (2016).

72 Sutton, R. J., Eperon, G. E., Miranda, L., Parrott, E. S., Kamino, B. A., Patel, J. B., Hörantner, M. T., Johnston, M. B., Haghighirad, A. A., Moore, D. T. \& Snaith, H. J. Bandgap-Tunable Cesium Lead Halide Perovskites with High Thermal Stability for Efficient Solar Cells. Advanced Energy Materials 6, 1502458, (2016).

73 McMeekin, D. P., Sadoughi, G., Rehman, W., Eperon, G. E., Saliba, M., Hörantner, M. T., Haghighirad, A., Sakai, N., Korte, L., Rech, B., Johnston, M. B., Herz, L. M. \& Snaith, H. J. A mixed-cation lead mixed-halide perovskite absorber for tandem solar cells. Science 351, 151-155, (2016).

74 Bowring, A. R., Bertoluzzi, L., O’Regan, B. C. \& McGehee, M. D. Reverse Bias Behavior of Halide Perovskite Solar Cells. Advanced Energy Materials 8 , 1702365, (2018).

75 Wang, Z., McMeekin, D. P., Sakai, N., van Reenen, S., Wojciechowski, K., Patel, J. B., Johnston, M. B. \& Snaith, H. J. Efficient and Air-Stable Mixed-Cation Lead Mixed-Halide Perovskite Solar Cells with n-Doped Organic Electron Extraction Layers. Advanced Materials 29, 1604186, (2017).

76 Wang, Z., Lin, Q., Chmiel, F. P., Sakai, N., Herz, L. M. \& Snaith, H. J. Efficient ambient-air-stable solar cells with 2D-3D heterostructured butylammonium-caesium-formamidinium lead halide perovskites. Nature Energy 2, 17135, (2017).

77 Leguy, A. M. A., Hu, Y., Campoy-Quiles, M., Alonso, M. I., Weber, O. J., Azarhoosh, P., van Schilfgaarde, M., Weller, M. T., Bein, T., Nelson, J., Docampo, P. \& Barnes, P. R. F. Reversible Hydration of $\mathrm{CH}_{3} \mathrm{NH}_{3} \mathrm{PbI}_{3}$ in Films, Single Crystals, and Solar Cells. Chemistry of Materials 27, 3397-3407, (2015).

78 Alsari, M., Pearson, A. J., Wang, J. T.-W., Wang, Z., Montisci, A., Greenham, N. C., Snaith, H. J., Lilliu, S. \& Friend, R. H. Degradation Kinetics of Inverted Perovskite Solar Cells. Scientific Reports 8, 5977, (2018).

79 Cheacharoen, R., Rolston, N., Harwood, D., Bush, K. A., Dauskardt, R. H. \& McGehee, M. D. Design and understanding of encapsulated perovskite solar cells to withstand temperature cycling. Energy \& Environmental Science 11, 144-150, (2018).

80 Yuan, Y. \& Huang, J. Ion Migration in Organometal Trihalide Perovskite and Its Impact on Photovoltaic Efficiency and Stability. Accounts of Chemical Research 49, 286-293, (2016).

81 Snaith, H. J., Abate, A., Ball, J. M., Eperon, G. E., Leijtens, T., Noel, N. K. Stranks, S. D., Wang, J. T.-W., Wojciechowski, K. \& Zhang, W. Anomalous Hysteresis in Perovskite Solar Cells. The Journal of Physical Chemistry Letters 5, 1511-1515, (2014)

82 Xiao, Z., Yuan, Y., Shao, Y., Wang, Q., Dong, Q., Bi, C., Sharma, P., Gruverman, A. \& Huang, J. Giant switchable photovoltaic effect in organometal trihalide perovskite devices. Nature Materials 14, 193, (2014).

83 Tress, W., Marinova, N., Moehl, T., Zakeeruddin, S. M., Nazeeruddin, M. K. \& Grätzel, M. Understanding the rate-dependent J-V hysteresis, slow time component, and aging in $\mathrm{CH}_{3} \mathrm{NH}_{3} \mathrm{PbI}_{3}$ perovskite solar cells: the role of a compensated electric field. Energy \& Environmental Science 8, 995-1004, (2015).

84 Zhang, Y., Liu, M., Eperon, G. E., Leijtens, T. C., McMeekin, D., Saliba, M., Zhang, W., de Bastiani, M., Petrozza, A., Herz, L. M., Johnston, M. B., Lin, H. \& Snaith, H. J. Charge selective contacts, mobile ions and anomalous hysteresis in organic-inorganic perovskite solar cells. Materials Horizons 2, 315-322, (2015).

85 Snaith, H. J. The perils of solar cell efficiency measurements. Nature Photonics 6, 337, (2012).

86 Zimmermann, E., Ehrenreich, P., Pfadler, T., Dorman, J. A., Weickert, J. \& Schmidt-Mende, L. Erroneous efficiency reports harm organic solar cell research. Nature Photonics 8, 669, (2014).

87 Eggenhuisen, T. M., Galagan, Y., Biezemans, A. F. K. V., Slaats, T. M. W. L., Voorthuijzen, W. P., Kommeren, S., Shanmugam, S., Teunissen, J. P., Hadipour, A., Verhees, W. J. H., Veenstra, S. C., Coenen, M. J. J., Gilot, J., Andriessen, R. \& Groen, W. A. High efficiency, fully inkjet printed organic solar cells with freedom of design. Journal of Materials Chemistry A 3, 7255-7262, (2015).

88 Hoth, C. N., Schilinsky, P., Choulis, S. A. \& Brabec, C. J. Printing Highly Efficient Organic Solar Cells. Nano Letters 8, 2806-2813, (2008).

89 Ramanujam, J. \& Singh, U. P. Copper indium gallium selenide based solar cells - a review. Energy \& Environmental Science 10, 1306-1319, (2017).
90 Jackson, P., Wuerz, R., Hariskos, D., Lotter, E., Witte, W. \& Powalla, M. Effects of heavy alkali elements in $\mathrm{Cu}(\mathrm{In}, \mathrm{Ga}) \mathrm{Se} 2$ solar cells with efficiencies up to 22.6\%. physica status solidi (RRL) - Rapid Research Letters 10, 583-586, (2016).

91 MiaSole, http://miasole.com/ (2018).

92 Hanergy, http://www.hanergy.com/en/ (2018).

93 NREL U.S. Solar Photovoltaic System Cost Benchmark Q1 2017 Report, https:// data.nrel.gov/submissions/73 (2018).

94 Søndergaard, R. R., Hösel, M. \& Krebs, F. C. Roll-to-Roll fabrication of large area functional organic materials. Journal of Polymer Science Part B: Polymer Physics 51, 16-34, (2012).

95 Espinosa, N., García-Valverde, R., Urbina, A. \& Krebs, F. C. A life cycle analysis of polymer solar cell modules prepared using roll-to-roll methods under ambient conditions. Solar Energy Materials and Solar Cells 95, 1293-1302, (2011).

96 Angmo, D., Gevorgyan, S. A., Larsen-Olsen, T. T., Søndergaard, R. R., Hösel, M., Jørgensen, M., Gupta, R., Kulkarni, G. U. \& Krebs, F. C. Scalability and stability of very thin, roll-to-roll processed, large area, indium-tin-oxide free polymer solar cell modules. Organic Electronics 14, 984-994, (2013).

97 Mazzio, K. A. \& Luscombe, C. K. The future of organic photovoltaics. Chemical Society Reviews 44, 78-90, (2015).

98 Song, S., Hill, R., Choi, K., Wojciechowski, K., Barlow, S., Leisen, J., Snaith, H. J., Marder, S. R. \& Park, T. Surface modified fullerene electron transport layers for stable and reproducible flexible perovskite solar cells. Nano Energy 49, 324-332, (2018).

99 Di Giacomo, F., Fakharuddin, A., Jose, R. \& Brown, T. M. Progress, challenges and perspectives in flexible perovskite solar cells. Energy \& Environmental Science 9, 3007-3035, (2016).

100 Saliba, M., Matsui, T., Seo, J.-Y., Domanski, K., Correa-Baena, J.-P., Nazeeruddin, M. K., Zakeeruddin, S. M., Tress, W., Abate, A., Hagfeldt, A. \& Grätzel, M. Cesium-containing triple cation perovskite solar cells: improved stability, reproducibility and high efficiency. Energy \& Environmental Science 9, 19891997, (2016).

101 Correa Baena, J. P., Steier, L., Tress, W., Saliba, M., Neutzner, S., Matsui, T., Giordano, F., Jacobsson, T. J., Srimath Kandada, A. R., Zakeeruddin, S. M., Petrozza, A., Abate, A., Nazeeruddin, M. K., Grätzel, M. \& Hagfeldt, A. Highly efficient planar perovskite solar cells through band alignment engineering. Energy \& Environmental Science 8, 2928-2934, (2015).

102 Yang, W. S., Noh, J. H., Jeon, N. J., Kim, Y. C., Ryu, S., Seo, J. \& Seok, S. I. High-performance photovoltaic perovskite layers fabricated through intramolecular exchange. Science 348, 1234-1237, (2015).

103 Lee, J.-W., Kim, H.-S. \& Park, N.-G. Lewis Acid-Base Adduct Approach for High Efficiency Perovskite Solar Cells. Accounts of Chemical Research 49, 311319, (2016).

104 Noel, N. K., Habisreutinger, S. N., Wenger, B., Klug, M. T., Hörantner, M. T., Johnston, M. B., Nicholas, R. J., Moore, D. T. \& Snaith, H. J. A low viscosity, low boiling point, clean solvent system for the rapid crystallisation of highly specular perovskite films. Energy \& Environmental Science 10, 145-152, (2017).

105 Kim, T. H. \& Kim, S. G. Clinical Outcomes of Occupational Exposure to N,N-Dimethylformamide: Perspectives from Experimental Toxicology. Safety and Health at Work 2, 97-104, (2011).

106 Wei, Z., Chen, H., Yan, K. \& Yang, S. Inkjet Printing and Instant Chemical Transformation of a $\mathrm{CH}_{3} \mathrm{NH}_{3} \mathrm{PbI}_{3} /$ Nanocarbon Electrode and Interface for Planar Perovskite Solar Cells. Angewandte Chemie International Edition 53, 13239-13243, (2014).

107 Hwang, K., Jung, Y.-S., Heo, Y.-J., Scholes, F. H., Watkins, S. E., Subbiah, J., Jones, D. J., Kim, D.-Y. \& Vak, D. Toward Large Scale Roll-to-Roll Production of Fully Printed Perovskite Solar Cells. Advanced Materials 27, 1241-1247, (2015).

108 Barrows, A. T., Pearson, A. J., Kwak, C. K., Dunbar, A. D. F., Buckley, A. R. \& Lidzey, D. G. Efficient planar heterojunction mixed-halide perovskite solar cells deposited via spray-deposition. Energy \& Environmental Science 7, 29442950, (2014).

109 Heliatek, https://www.heliatek.com/en/ (2018).

110 Borchert, J., Milot, R. L., Patel, J. B., Davies, C. L., Wright, A. D., Martínez Maestro, L., Snaith, H. J., Herz, L. M. \& Johnston, M. B. Large-Area, Highly 
Uniform Evaporated Formamidinium Lead Triiodide Thin Films for Solar Cells. ACS Energy Letters 2, 2799-2804, (2017).

111 Hutter, E. M., Sutton, R. J., Chandrashekar, S., Abdi-Jalebi, M., Stranks, S. D., Snaith, H. J. \& Savenije, T. J. Vapour-Deposited Cesium Lead Iodide Perovskites: Microsecond Charge Carrier Lifetimes and Enhanced Photovoltaic Performance. ACS Energy Letters 2, 1901-1908, (2017).

112 Perovskite photovoltaic: A review of the patent landscape, http://www.osadirect.com/news/article/2062/perovskite-photovoltaic-a-review-of-the-patent-landscape-2017-q4/ (2018).

113 Hangzhou Microquanta Semiconductor, http://microquanta.com/ (2018).

114 Saule Technologies, https://sauletech.com/ (2018).

115 Hunt Energy Enterprises, http://www.huntenergyenterprises.com/ (2018).

116 Swift Solar, https://www.swiftsolar.com/ (2018).

\section{Conflicts of Interest}

Henry Snaith is co-founder and Chief Scientific Officer of Oxford PV.

\section{Author Contributions}

HS was interviewed by SL, who shot, edited, and prepared the artwork for the video.

\section{Keywords}

Perovskite photovoltaics, perovskite review, commercial perovskite, perovskite solar cells, perovskite on silicon, multi-junction perovskite, perovskite degradation, perovskite video.

\section{Article Information}

This article is licensed by Henry J. Snaith and Samuele Lilliu under a Creative Commons Attribution 4.0 International License (CC BY 4.0). 